\title{
METODE BERCERITA DALAM PEMBELAJARAN MENYIMAK DI KELAS V SEKOLAH DASAR
}

\author{
Sinsin Kartini*)
}

\begin{abstract}
Abstrak
Penelitian ini dilatarbelakangi oleh hasil studi pendahuluan yang menunjukan kemampuan menyimak siswa kelas V SD Negeri Mekarsari yang hanya mencapai nilai rata-rata 55 dalam tes kemampuan menyimak. Sedangkan Standar Kemampuan Minimal untuk mata pelajaran bahasa Indonesia adalah 65. Hal tersebut disebabakan oleh beberapa faktor, diantaranya, guru kurang tepat memilih metode, materi yang disampaikan kurang menarik, dan siswa kurang memahami perbendaharaan kata dalam bahasa Indonesia.

Berdasarkan masalah tersebut, penelitian ini bertujuan untuk (1) memperoleh gambaran pelaksanaan pembelajaran menyimak dengan menggunakan metode bercerita, (2) mengetahui aaktivitas pembelajaran menyimak melalui penggunaan metode bercerita, dan (3) memperoleh gambaran hasil menyimak siswa kelas V SD Negeri Mekarsari setelah menggunakan metode bercerita. Penelitian ini menggunakan metode deskriptif kualitatif dengan pendekatan penelitian tindakan kelas (PTK) model Elliot, yang disusun secara berdaur dalam tiap siklusnya yang meliputi perencanaan, pelaksanaan, pemantauan, dan refleksi. Data yang diperoleh dari hasil penelitian ini menyangkut prilaku siswa kelas V sebanyak 28 orang. Instrumen yang digunakan dalam penelitian adalah lembar catatan lapangan,lembar observasi, pedoman wawancara, dan evaluasi. Evaluasi hasil dipokuskan pada hasil kemampuan menyimak siswa setelah pelaksanaan pembelajaran.

Pelaksanaanpembelajaran menyimak dengan metode bercerita pada siswa kelas V SD Negeri Mekarsari ini dilaksanakan dalam tiga siklus. Setiap siklus terdiri dari satu tindakan. Setiap tindakan pembelajaran dipokuskan pada menceritakan kembali isi cerita. Evaluasi hasil pelaksanaan tindakan siklus I memperoleh nilai rata-rata kelas 72. Pelaksanaan tindakan siklus II memperoleh nilai rata-rata kelas 79. Pelaksanaan tindakan siklus III memperoleh nilai rata-rata kelas 86. Evaluasi hasil pelaksanaan tindakan tersebut menunjukkan adanya peningkatan nilai siswa pada setiap siklusnya.
\end{abstract}

\section{Kata Kunci: Metode Bercerita; Pembelajaran Menyimak}

\section{A. Pendahuluan}

Pelajaran menyimak di sekolah dasar merupakan bagian dari pembelajaran bahasa Indonesia. Menyimak merupakan dasar pengetahuan berbahasa yang sangat fungsional yang lebih bermakna bagi manusia untuk mengungkap lambang-lambang kata dari orang kedua yang merupakan suatu proses mendengarkan bunyi bahasa, mengidentifikasi, menilai dan mereaksi atas makna yang terkandung didalamnya. 
Menyimak adalah mendengarkan dan memahami isi bahan simakan. Tujuan utama menyimak adalah menangkap, memahami atau menghayati pesan, ide, gagasan yang tersirat dalam bahan simakan (Tarigan, 1994: 6).

Berdasarkan tujuan tersebut penulis mencoba melaksanakan observasi awal pada siswa kelas V sekolah dasar. Setelah penulis teliti ternyata kualitas pembelajaran menyimak pada pelajaran bahasa Indonesia sangat rendah. Hal ini dapat dilihat dari nilai rata-rata siswa kelas $\mathrm{V}$ dalam tes kemampuan menyimakyang hanya mencapai 55. Sedangkan SKM untuk mata pelajaran bahasa Indonesia yaitu 65. Hal tersebut disebabkan oleh beberapa faktor, diantaranya guru kurang tepat memilih metode, materi yang disampaikan kurang menarik, dan siswa kurang memahami perbendaharaan kata.

Untik mengatasi ketiga masalah tersebut, penulis perlu mengadakan tindakan agar kemampuan siswa meningkat. Hal ini didasarkan pada pendapat Resmini, dkk (2006:82) bahwa,” ... siswa perlu diberi kesempatan sebanyakbanyaknya agar menjadi penyimak yang baik dan efisien. Untuk meningkatkan kemampuan menyimak siswa tersebut, dalam penelitian ini, penulis menggunakan metode bercerita, karena metode bercerita memiliki kesejajaran dengan dongeng sebelum tidur yang biasa dilakukan oleh orangtua dulu, untuk mengembangkan imajinasi, fantasi, dan daya kognisi yang akan mengarahkan anak pada pemahaman yang baik pada pengenalan alam dan lingkungan serta pengenalan perasaan fikiran tentang diri sendiri dan orang lain.

Sejalan dengan latar belakang masalah di atas, ditemukan masalah yang operasional sebagai berikut.

1. Bagaimana pelaksanaan menyimak melalui metode bercerita?

2. Bagaimana aktivitas pelaksanaan pembelajaran menyimak melalui penggunaan metode bercerita di kelas V SD Negeri Mekarsari?

3. Bagaimana hasil kemampuan menyimak siswa kelas V SD Negeri Mekarsari setelah menggunakan metode bercerita?

Berdasarkan rumusan masalah tersebut, penelitian ini bertujuan.

1. Memperoleh gambaran pelaksanaan pembelajaran menyimak dengan menggunakan metode bercerita.

2. Mengetahui aktivitas pembelajaran menyimak melalui penggunaan metode bercerita.

3. Memperoleh gambaran hasil menyimak siswa kelas V SD Negeri Mekarsari setelah penggunaan metode bercerita. 


\section{B. KAJIAN PUSTAKA}

\section{Hakikat Metode Bercerita}

Cerita atau dongeng merupakan salah satu bentuk hiburan yang dapat dinikmati siapa saja. Namun sampai saat ini yang menjadi sasaran utamanya adalah anak-anak. Dongeng menurut Resmini dan Hartati (2006:81) adalah menuturkan atau membentangkan terjadinya peristiwa yang dipaparkan didalamnya bukan hanya garis besar peristiwanya saja melainkan diperinci juga hal yang bersangkut paut dengan peristiwa tersebut seperti: sosok pelakunya, watak-wataknya, tempat dan suasana itu terjadi, waktu dan latar belakang peristiwa itu terjadi.

Lestari (Bakar, 2006:16) menyatakan bahwa dongeng adalah paparan rekaan tentang kejadian atau aktivitas yang berhubungan dengan suatu tokoh dalam konteks tertentu. Secara keseluruhan, rangkaian kejadian dan karakter ini membentuk suatu alur yang utuh dan penggubahannya di maksudkan sebagai hiburan, wahana ajaran moral atau keduanya.

Bakar (2006:16) mengatakan bahwa dongeng memiliki sifat khayali (tak mesti faktual) dan koheren (terpadu) dongeng menjadi memiliki kekuatan magis, sehingga membuat anak-anak gampang mencerna pelajaran di dalamnya dan member konteks yang “wajar” sebagai sarang "ajaran” tentang kehidupan dan menjadi bentuk kegiatan bahasa yang populer bagi anak. Melalui kegiatan ini kemampuan anak dalam menyimak akan dapat berkembang dengan baik karena cerita merupakan bentuk sastra yang didengar dan disampaikan oleh guru kepada siswanya sementara telinga menjadi media dalam penyimakan cerita selain itu mendengarkan verita lebih mudah dan lebih mengasyikkan bagi siswa tingkat dasar dari pada membacanya sendiri.

Bercerita dapat menyentuh berbagai aspek pembentukan kepribadian anakanak. Manfaat cerita bagi kepribadian anak menurut Hidayati (http//www.niahidayati.net) adalah mengembangkan kemampuan berbicara dan memperkaya kosa kata anak karena secara tidak langsung kita telah mengajarkan perbendaharaan kata melalui cerita. Bercerita dapat melatih dan memperkaya kemampuan berbahasa dan memahami struktur kalimat yang lebih kompleks. Bercerita dapat memberikan efek menyenangkan, bahagia dan ceria, khususnya bila cerita tang disajikan adalah cerita lucu. Bercerita dapat melatih dan mengembangkan mengembangkan kecerdasan anak secara intelgen (kognitif), emosional (afektif), spiritual dan visual anak. Secara kognitif yaitu akan mempermudah proses pembelajaran pada anak, karena kemampuan berpikir otak lebih mudah menyerap nilai yang terkandung di dalam cerita. Secara afektif cerita akan mempengaruhi suasana hati dan menumbuhkan perasaan-perasaan empati dan positif pada anak. Secara spiritual, cerita dapat menggugah persaan rohani, 
menyentuh bagian terdalam bagi anak, serta melatih kemampuan, kemauan dan kecerdasan mereka akan keberadaan Tuhan dalam hidup mereka. Bercerita merupakan cara paling baik untuk mendidik tanpa kekerasan, menanamkan nilai moral dan etika juga kebenaran, serta melatih kedisiplinan.

Cerita bagi anak-anak biasanya mempunyai karakter baik dan jahat yang dapat dijadikan bahan pengait cerita yang akan menjadi bahan pengingat. Dalam isi dongeng yang mempunyai karakter yang baik selalu menang walaupun jumlahnya kecil. Oleh karena itu anak yang mendengarkan dongeng akan selalu ingat pada isi dongeng tersebut dan kemampuan mengingat isi dongeng tersebut merupakan kemampuan untuk melatih keterampilan menyimak.

Guru yang akan menggunakan bercerita atau mendongeng sebagai sebuah metode pembelajaran bahasa, hendaknya memilih tema cerita yang cocok dengan usia anak, mempersiapkannya dan menyampaikannya kepada pendengar dengan baik. Agar kegiatan bercerita sesuai dengan yang diharapkan, guru harus menguasai cara-cara mendongeng yang baik. Adapun cara-cara mendongeng yang kreatif adalah sebagai berikut.

\section{Tahap Persiapan}

a. Memilih materi dongeng/cerita:,

1) ceritanya harus menarik bagi anak;

2) temanya harus sesuai dan bermanfaat untuk anak;

3) mengandung unsure mendidik; dan

4) materi dongeng harus beragam agar anak tidak mengalami kejenuhan.

b. Memilih Media

Media yang digunakan dalam kegiatan mendongeng harus menarik, ekonomis, praktis, fungsional, serta aman apabila digunakan oleh anak.

c. Melakukan Latihan

Latihan-latihan yang harus dilakukan sebelum kegiatan mendongeng yaitu: gerak, ekspresi, suara, penggunaan media, dan latihan memahami cerita.

2. Tahap Pelaksanaan

a. Memilih media yang tepat untuk mendongeng.

b. Memulai kegiatan dengan apersepsi.

c. Mendongeng dengan penuh penghayatan.

d. Menghidupkan suasana mendongeng, dengan cara:,

1) menyesuaikan suara dengan karakter tokoh cerita;

2) menggunakan ekspresi dengan tepat;

3) dialog harus optimal;

4) melibatkan anak dalam cerita; dan

5) membumbui cerita dengan sedikit humor.

3. Tahap Pasca Mendongeng 
a. Memberikan kesempatan pada siswa untuk beraktivitas/berkreatifitas.

b. Memberi kesempatan pada siswa untuk memberikan respon atau member tanggapan tentang dongeng tersebut.

c. Mengajak siswa bermain peran.

d. Mengadakan evaluasi tentang isi dongeng.

e. Mengulas isi dongeng (pesan dan kesan).

\section{Hakikat Menyimak}

\section{a. Pengertian Menyimak}

Keterampilan menyimak sering disamakan dengan keterampilan mendengar dan mendengarkan. Mendengar, mendengarkan, dan menyimak sesungguhnya merupakan istilah yang berbeda artinya. Masing-masing istilah tersebut berdiri sendiri dengan makna yang berbeda pula. Kegiatan mendengar terjadi secara kebetulan, tidak sengaja dan tidak dilaksanakan. Pada peristiwa mendengarkan sudah ada unsur kesengajaan akan tetapi belum diikuti unsur pemahaman. Sedangkan pada peristiwa menyimak ada unsur kesengajaan, direncanakan yang disertai dengan penuh perhatian dan minat.

Perbedaan mendengar, mendengarkan, dan menyimak lebih rinci diungkapkan oleh Tarigan (1995:2-3) bahwa:

Peristiwa mendengar, biasanya terjadi secara kebetulan, tiba-tiba, dan tidak diduga sebelumnya. Oleh karena itu kegiatan mendengar tidak direncanakan. ... mendengarkan setingkat lebih tinggi tarafnya dari mendengar. Peristiwa mendengarkan sudah ada faktor kesengajaan. Factor pemahaman mungkin tidak ada karena belum menjadi tujuan. ... peristiwa menyimak sudah ada faktor kesengajaan. Faktor pemahaman sudah menjadi unsure utama dalam setiap peristiwa menyimak.

Selanjutnya Tarigan (1995:4) mengungkapkan bahwa "menyimak adalah suatu proses yang mencakup kegiatan mendengarkan bunyi bahasa, mengidentifikasi, menginterpretasi, menilai dan mereaksi atas makna yang terkandung didalamnya”.

Tarigan (1994:32) berpendapat bahwa:

Menyimak adalah suatu proses kegiatan mendengarkan lambing-lambang lisan dengan penuh perhatian, pemahan, apresiasi, serta interpretasi untuk memperoleh informasi, menangkap informasi atau pesan serta memahami makna komunikasi yang telah disampaikan oleh sang pembicara melalui ujaran atau bahasa lisan.

Berdasarkan kedua pendapat tersebut, dapat disimpulkan bahwa menyimak adalah suatu kegiatan mendengar bunyi bahasa dengan penuh perhatian, interpretasi, pemahaman, apresiasi, evaluasi dan responsi. 
Dalam pembelajaran yang dilatihkan kemampuan menyimak dalam [pelaksanaannya dipadukan dengan kemampuan bahasa yang lain.

\section{b. Tujuan Menyimak}

Tarigan (1995:4) berpendapat bahwa “Tujuan utama menyimak adalah menangkap, memahami, atau menghayati pesan, ide, gagasan, yang tersirat dalam bahan simakan”. Tarigan kemudian mengklasifikasikan tujuan tersebut yakni menyimak untuk mendapatkan fakta, menganalisis fakta, mengevaluasi fakta, mendapatkan inspirasi, menghibur diri dan meningkatkan kemampuan berbicara.

\section{c. Kemampuan Menyimak Siswa SD}

Khusus mengenai kemampuan menyimak siswa sekolah dasar yang telah meninggalkan masa taman kanak-kanaknya menurut Anderson (Tarigan, i994:24) sebagai berikut.

1. Anak-anak akan mampu menyimak dengan baik, apabila suatu cerita dibacakan dengan nyaring.

2. Anak-anak akan senang dan mampu menyimak dengan baik, apabila seorang pembicara menceritakan suatu pengalaman sejati.

3. Anak-anak dapat menyimak bunyi-bunyi dan nada-nada yang berbeda, terlebih kalau nada, terlebih kalau intonasi sang pembicara sangat jelas dan baik.

4. Anak-anak dapat menyimak serta menuruti petunjuk-petunjuk lisan yang disampikan dengan jelas.

5. Anak-anak mampu menyimak persamaan-persamaan dan perbedaanperbedaan yang terdapat dalam ujaran.

6. Anak-anak mampu dan senang menyimak ritme-ritme dan rima-rima dalam suatu pembacaan puisi atau drama.

7. Anak-anak mampu menyimak dan menangkap ide-ide yang terdapat dalam ujaran atau pembicaraan.

Berdasarkan pernyataan tersebut dalam proses pembelajaran menyimak dibutuhkan kekreatifan dari seorang guru dalam menyajikan bahan simakan bagi siswa, sehingga siswa bukan hanya menyimak dengan baik namun siswa akan senang karena merasa terhibur.

\section{METODE PENELITIAN}

Metode yang digunakan dalam penelitian ini adalah metode Penelitian Tindakan Kelas (PTK) yang bersifat deskriptif. Penelitian tindakan kelas merupakan upaya guru untuk memperbaiki pembelajaran baik secara individual, kelompok, maupun secara klasikal agar mempunyai gambaran kegiatan yang dipraktekkan oleh guru di dalam kelas.

Mc Taggart ( Hermawan, 2007:233) menjelaskan bahwa penelitian tindakan [kelas] adalah suatupendekatan untuk memperbaiki pengajaran dengan cara melanjutkan perubahan-perubahan dan mempelajari akibat-akibat dari perubahan- 
perubahan itu, jenis dan sifat perubahan tersebut dapat terjadi sebagai hasil mengajar relatif.

Penelitian dilaksanakan di SD Negeri Mekarsari, Kecamatan Sindangbarang, Kabupaten Cianjur. Subyek utama dalam penelitian ini adalah siswa kelas V, yang berjumlah 28 orang, dengan rincian siswa laki-laki 15 orang dan siswa perempuan berjumlah 13 orang.

Penelitian dilaksanakan dalam dua tahap, yaitu tahap studi pendahuluan dan tahap pelaksanaan penelitian. Pada tahap studi pendahuluan penulis melakukan pengamatan untuk meneliti kondisi awal menyimak siswa kelas V. pada dasarnya penelitian tersebut merupakan tindakan untuk pemecahan masalah praktis dalam pembelajaran menyimak yang mempengaruhi pada perbaikan dan pengembangan profesionalisme guru. Tahap kedua yaitu pelaksanaan penelitian, yang meliputi perencanaan, pelaksanaan, pemantauan, dan refleksi.

Instrumen penelitian yang digunakan adalah pedoman wawancara, catatan lapangan, lembar observasi dan tes. Aspek-aspek penilaian yang dipakai dalam tes menceritakan kembali isi cerita secara tertulis yaitu sebagai berikut.

a. Kesesuaian Isi Cerita dengan Cerita Asli

$3=$ sesuai

$2=$ kurang sesuai

$1=$ tidak sesuai

b. Keruntutan Penceritaan

$3=$ runtut

$2=$ kurang runtut

$1=$ tidak runtur

c. Struktur Kalimat

$3=$ baku

$2=$ kurang baku

$1=$ tidak baku

d. Kesesuaian Kalimat dengan EYD

$3=$ sesuai

$2=$ kurang sesuai

$1=$ tidak sesuai

Pengolahan nilainya adalah sebagai berikut.

Nilai = Skor yang diperoleh $\mathrm{x} 100$

Skor Ideal 


\section{HASIL PENELITIAN DAN PEMBAHASAN}

Pelaksanaan penelitian yang penulis lakukan adalah untuk meningkatkan kemampuan menyimak siswa melalui metode bercerita. Dalam pelaksanaannya penelitian dilakukan dalam tiga siklus. Setiap siklus terdiri dari satu tindakan.

Pada pelaksanaan tindakan siklus I, siswa tampak pesimis dengan tujuan pembelajaran menceritakan kembali isi cerita. Tetapi siswa tampak antusias dengan media gambar yang digunakan penulis ketika menyampaikan cerita. Selanjutnya ketika penulis membawakan cerita, terdapat siswa yang ngobrol, sehingga penulis terpaksa memberhentikan dulu kegiatan berceritanya, dan menegur siswa tersebut untuk menghentikan kegiatannya. Saat penulis mengadakan tanya jawab mengenai cerita yang baru disampaikan siswa masih menggunakan bahasa Sunda baik ketika mengajukan pertanyaan, menjawab pertanyaan, maupun memberi komentar. Dalam menjawab pertanyaan dan member tanggapan siswa cukup baik, tetapi dalam mengajukan pertanyaan siswa kurang berani Pada saat diskusi kelompok terdapat beberapa orang siswa yang kurang serius dalam mengerjakan tugas kelompoknya, sehingga penulis berusaha membangkitkan motivasi terhadap siswa tersebut untuk sungguh-sungguh bertanggungjawab terhadap tugasnya. Pada siklus ini kegiatan diskusi diisi dengan kegiatan kuis “Tanya-Tepat, Jawab_Tepat”. Siswa cukup antusias dalam mengikuti kegiatan tersebut. Pelaksanaan tindakan siklus I kelas belum terkondisi dengan baik.

Pada tindakan siklus II, penulis mengatur tempat duduk siswa. Siswa yang suka ngobrol dipindahkan ke depan agar siswa dapat mengkonsentrasikan perhatiannya pada pembelajaran yang akan dilaksanakan, dan diharapkan siswa tersebut tidak ngobrol lagi. Pada saat penulis sedang bercerita masih terdapat siswa yang konsentrasinya memudar. Siswa tersebut mencoba untuk mengajak ngobrol temannya, penulis segera memberi kode agar siswa tersebut menyimak ceritanya. Pada sesi tanya jawab beberapa siswa secara refleks masih menggunakan bahasa Sunda. Keberanian siswa dalam membacakan hasil simakan ceritanya sudah mulai tampak, begitu pula dengan hasil evaluasi dari menceritakan kembali isi cerita secara tertulis sudah mulai ada peningkatan. Secara umum situasi kelas sudah mulai kondusif.

Pada tindakan siklus III, kegiatan diawali dengan memindahkan tempat duduk siswa yang nilainya masih kurang ke depan dengan harapan dapat konsentrasi dalam kegiatan menyimak cerita sehingga nilai yang diperoleh dapat meningkat. Aktivitas belajar baik dalam kegiatan diskusi maupun pada saat membacakan hasil simakannya sudah mengalami peningkatan, meskipun dalam kegiatan diskusi masih terdapat siswa yang mengajukan pertanyaan dengan menggunakan bahasa Sunda. Dalam kegiatan membacakan hasil simakan cerita 
siswa sudah tidak ragu-ragu lagi, begitu pun dengan hasil tes menyimak cerita sudah mengalami peningkatan dari siklus-siklus sebelumnya. Pada siklus III situasi kelas terkondisi dengan baik. Hasil penilaian tes menceritakan kembali secara tertulis dari siklus I sampai siklus III tampak pada tabel berikut ini.

Tabel 1

Rekapitulasi Hasil Tes Menceritakan Kembali Cerita Secara Tertulis dari Siklus I sampai Siklus III

\begin{tabular}{|c|c|c|c|c|c|c|c|}
\hline \multirow[t]{2}{*}{ NO } & \multirow[t]{2}{*}{ NAMA SISWA } & \multicolumn{2}{|c|}{ SIKLUS I } & \multicolumn{2}{|c|}{ SIKLUS II } & \multicolumn{2}{|c|}{ SIKLUS III } \\
\hline & & Skor & Nilai & Skor & Nilai & Skor & Nilai \\
\hline 1 & Aang $\mathrm{H}$ & 10 & 83 & 11 & 91 & 11 & 91 \\
\hline 2 & Andri G & 7 & 58 & 8 & 66 & 8 & 66 \\
\hline 3 & Ai T & 4 & 33 & 6 & 50 & 9 & 75 \\
\hline 4 & Dewai S & 9 & 75 & 10 & 83 & 9 & 75 \\
\hline 5 & Epi H & 12 & 100 & 11 & 91 & 12 & 100 \\
\hline 6 & Hamzah & 9 & 75 & 10 & 83 & 12 & 100 \\
\hline 7 & Handriana & 12 & 100 & 11 & 91 & 12 & 100 \\
\hline 8 & Herul N & 8 & 66 & 9 & 75 & 10 & 83 \\
\hline 9 & Idris & 12 & 100 & 11 & 91 & 12 & 100 \\
\hline 10 & Idis S & 5 & 41 & 8 & 66 & 9 & 75 \\
\hline 11 & Iis $\mathrm{N}$ & 7 & 58 & 9 & 75 & 10 & 83 \\
\hline 12 & Kesih S & 11 & 91 & 12 & 100 & 12 & 100 \\
\hline 13 & Miftah & 11 & 91 & 10 & 83 & 11 & 91 \\
\hline 14 & M Dedi R & 11 & 91 & 11 & 91 & 12 & 100 \\
\hline 15 & Mimih N & 9 & 75 & 8 & 66 & 9 & 75 \\
\hline 16 & Mistar & 11 & 91 & 10 & 83 & 12 & 100 \\
\hline 17 & Paisal N & 7 & 58 & 6 & 50 & 7 & 58 \\
\hline 18 & Resnawati & 9 & 75 & 9 & 75 & 10 & 83 \\
\hline 19 & Sri Wulan & 5 & 41 & 7 & 58 & 9 & 75 \\
\hline 20 & Sirojul M & 9 & 75 & 11 & 91 & 11 & 91 \\
\hline 21 & Siti A & 6 & 50 & 9 & 75 & 10 & 83 \\
\hline 22 & Siti M & 7 & 58 & 10 & 83 & 10 & 83 \\
\hline 23 & Sahrul G & 8 & 66 & 10 & 100 & 12 & 100 \\
\hline 24 & Titi Rosi L & 12 & 100 & 11 & 91 & 12 & 100 \\
\hline 25 & Yuyu N & 12 & 100 & 12 & 100 & 12 & 100 \\
\hline 26 & Tarsika & 4 & 33 & 6 & 50 & 7 & 58 \\
\hline 27 & Abdul A & 8 & 66 & 9 & 75 & 10 & 83 \\
\hline 28 & Abdussalim & 8 & $\begin{array}{l}66 \\
72\end{array}$ & 10 & $\begin{array}{l}83 \\
79\end{array}$ & 11 & $\begin{array}{l}91 \\
86\end{array}$ \\
\hline & & & 72 & & 79 & & 86 \\
\hline
\end{tabular}

Skor tertinggi 12

Skor terendah 7 
Berdasarkan data tersebut dapat diketahui tingkat kemampuan menyimak cerita dalam tes kemampuan menceritakan kembali isi cerita secara tertulis pada setiap siklusnya mengalami peningkatan, meskipun lima orang siswa mengalami penurunan pada siklus II tetapi pada siklus III kembali meningkat. Pada pelaksanaan tindakan siklus I rata-rata siswa memperoleh nilai 72. Pada pelaksanaan tindakan siklus II siswa memperoleh nilai rata-rata 79 dan pada pelaksanaan tindakan siklus III siswa memperoleh nilai rata-rata 86. Data hasil pelaksanaan pembelajaran tersebut menunjukkan perolehan nilai siswa meningkat dengan menunjukkan nilai yang lebih baik pada setiap siklusnya.

\section{E. Kesimpulan dan Saran}

Berdasarkan hasil penelitian tindakan kelas yang dilaksanakan sebanyak tiga siklus yang telah penulis lakukan, penulis dapat menaruk kesimpulan, yaitu.

1. Aktivitas belajar siswa dalam pembelajaran menyimak cukup meningkat. Hal tersebut tampak dalam kegiatan diskusi dan kegiatan membacakan hasil simakan cerita. Dalam kegiatan diskusi yang dilakukan pada setiap siklusnya dapat meningkatkan partisipasi siswa secara aktif dalam kegiatan tersebut, begitu pun dalam kegiatan menceritakan kembali isi cerita secara tertulis keberanian siswa untuk membacakan hasil simakan ceritanya semakin meningkat.

2. Penggunakan metode bercerita dalam pembelajaran menyimak, terbukti dapat meningkatkan hasil belajar siswa. Hal tersebut terbukti dengan terus meningkatnya hasil penilaian tes menceritakan kembali cerita pada setiap siklusnya.

Berdasarkan hasil penelitian tindakan kelas tentang metode bercerita dalam pembelajaran menyimak yang dilakukan pada siswa kelas $\mathrm{V}$ sekolah dasar, terdapat beberapa hal yang penulis sarankan, yaitu.

1. Penggunaan media gambar dalam pembelajaran menyimak juga dapat digunakan dalam keterampilan lainnya, seperti keterampilan berbicara, membaca dan menulis.

2. Untuk para guru, baik guru yang mengajar di kelas rendah atau pun yang mengajar di kelas tinggi, dapat mencoba menggunakan metode bercerita untuk membantu siswa dalam pembelajaran menyimak di kelas masing-masing. Cerita yang dipilih harus sesuai dengan tingkat perkembangan dan karakteristik siswa.

3. Untuk memperoleh belajar yang maksimal seyogyanya guru melakukan penelitian tindakan kelas agar setiap permasalahan yang dihadapi dalam kegiatan belajar mengajar dapat teratasi. 
4. Agar siswa dapat berbahasa Indonesia dengan baik, diharapkan setiap guru menugaskan siswanya untuk banyak membaca buku sehingga selain dapat belajar bahasa Indonesia, kosa kata yang dimiliki siswa pun dapat meningkat.

\section{DAFTAR PUSTAKA}

Bakar, Z. (2006).” Penggunaan Strategi Induktif melalui Kegiatan Mendongeng (Storytelling) untuk Meningkatkan Kemampuan Anak dalam Menyimak”. Jurnal Pendidikan Dasar. IV (16) 16-18.

Hermawan, R. Mujono dan Suherman, A. (2007). Metode Penelitian Pendidikan Sekolah Dasar. Bandung: UPI Press.

Hidayati, N. (2008). Manfaat Cerita bagi Kepribadian Anak. [online]. Tersedia: http//www.niahidayati.net/2008/02/12/ manfaat_cerita_bagi_kepribadian_anak [7 Desember 2009].

Sulastri, I. (2009). Mendongeng Kreatif dalam Pembelajaran Menyimak di Kelas III Sekolah Dasar. Skripsi S-I PGSD UPI Bandung: tidak diterbitkan.

Resmini, N. dan Hartati, T. (2006). Kapita Selekta Bahasa Indonesia. Bandung: UPI Press.

Resmini, N. dkk. (2006). Pembinaan dan Pengembangan Bahasa dan Sastra Indonesia. Bandung: UPI Press.

Tarigan, D. (1995). Pendidikan Bahasa Indonesia I. Jakarta: Universitas Terbuka.

Tarigan, H.G. (1994). Menyimak sebagai suatu Keterampilan Berbahasa. Bandung: Angkasa.

Tarigan, H.G. (1986). Membaca sebagai suatu Keterampilan Berbahasa. Bandung: Angkasa.

*) Sinsin adalah alumni Program Studi PGSD Universitas Pendidikan Indonesia (UPI) Kampus Cibiru. Penulis adalah guru SD Negeri Mekarsari, Kecamatan Sindangbarang, Kabupaten Cianjur. 